\title{
Florida Wetlands: Extension Web Site ${ }^{1}$
}

\section{Mark Clark ${ }^{2}$}

Wetlands cover almost $30 \%$ of the state of Florida and account for just over $10 \%$ of the remaining wetland area in the lower 48 United States. Over the past 200 years Florida has lost an estimated 10 million acres of wetland, about half of the total area thought to exist in the 1780's. Some of these remaining wetlands are well known, like the Florida Everglades, while others may be small and unassuming. All play a vital role in flood protection, water quality and wildlife habitat. The Florida Wetlands Extension web site (http://wetlandextension.ifas.ufl.edu) is designed to provide you with a better understanding of wetlands and wetland-related issues in Florida where these ecosystems are such a prominent feature. Some of the subjects covered in the site include:

\section{All about Wetlands}

This section of the site explains the unique types of soils, vegetation and hydrologic characteristics that occur in a wetland. It also explains that not all wetlands are the same and outlines some of the characteristics of the dominant wetland community types found in Florida. There are also field guides and information you can use to identify and learn more about the wildlife and types of plants that live in wetlands.

\section{Wetlands Near You}

If you are curious about where the wetlands are in Florida, or if you want to visit and experience a wetland first hand, this section of the web site has maps that will show you the location of wetlands, uplands and open water for all 67 counties in Florida. You might be surprised how many wetlands are in your backyard. To take full advantage of this section, click on a county of interest. The next map that appears will show you where most of the wetlands in the county occur. You can also add city and roadways to the county map to get a better orientation. This same map will highlight wetlands that are accessible to the public and link you to more detailed information on how to get there, hiking trails and what you might see on your visit.

\section{In the News}

Wetland issues are always in the Florida news from restoring the Florida Everglades to the possible impacts of a new policy on wetland protection or development. This area of the site posts recent news articles and current issues about wetlands in Florida around the nation and globe. This section is organized into Wetland Events, Restoration Projects, Mitigation Projects, Constructed Wetlands,

1. This document is Fact Sheet SL217, one of a series of the Soil and Water Science Department, Florida Cooperative Extension Service, Institute of Food and Agricultural Sciences, University of Florida. Original publication date August 2004. Visit the EDIS Web Site at http://edis.ifas.ufl.edu.

2. Mark Clark, Research Assistant Professor, Wetland Ecology, Soil and Water Science Department, Florida Cooperative Extension Service, Institute of Food and Agricultural Sciences, University of Florida, Gainesville, 32611-0290.

The Institute of Food and Agricultural Sciences (IFAS) is an Equal Employment Opportunity - Affirmative Action Employer authorized to provide research, educational information and other services only to individuals and institutions that function without regard to race, creed, color, religion, age, disability, sex, sexual orientation, marital status, national origin, political opinions or affiliations. For information on obtaining other extension publications, contact your county Cooperative Extension Service office. Florida Cooperative Extension Service / Institute of Food and Agricultural Sciences / University of Florida / Larry R. Arrington, Interim Dean 
Legislation and Special Topics so you can quickly

find what you are looking for. There is also a calendar of upcoming wetland events you might want to attend.

\section{Current Research}

If you are looking for more in-depth information about wetlands or want to know the most recent findings from the research community, this section is for you. Some of the topics covered include:

Research in Natural Wetlands, Research on Wetlands

Mitigation and Policy Issues, and Research on Treatment Wetlands and Wetland Enhancement. There are also links to prominent Florida research programs so you can learn what the latest research efforts are finding.

\section{Education}

This section is set up for parents and educators of students in grades Pre-K through 12. There are numerous links to sites (mostly government and non-profit based) that have lesson plans for wetlands activities, including group experiments and investigations, reference material, fact sheets and even suggested reading. We hope this section provides most of the materials and some new ideas on how to understand and present the fundamental processes that occur in wetlands to your children and students.

\section{Regulations}

Preserving the function and value of wetlands for wildlife and society has resulted in a wide range of regulations at many levels of government. Although all the details of county-level ordinances addressing wetland regulations can not be covered on the site, this section outlines state and federal wetland policies and provides links to appropriate agencies and local governments where some of these specifics can be answered.

\section{Contact Us}

If you aren't able to find what you are looking for, this area allows you to submit wetland-related questions to the state extension specialist so you will still be able to get your wetland question answered.
We hope this site will provide a "one-stop-shop" for most of your wetland information needs. To visit the web site, point your browser to http://wetlandextension.ifas.ufl.edu. 